\title{
Public policy schools in the global south: a mapping and analysis of the emerging landscape
}

\author{
Ola G. El-Taliawi ${ }^{1}$ (D) . Sreeja Nair ${ }^{2}$ (D) $\cdot$ Zeger Van der Wal $^{3}$ (D)
}

Accepted: 31 October 2020 / Published online: 9 January 2021

(c) The Author(s) 2021

\begin{abstract}
Public policy education in the Global South has mushroomed in the past 2 decades, concomitant with governance models that provide an alternative to liberal Western democracies. However, not much empirical evidence exists on the drivers and implications of this trend, with few exceptions that point toward a form of internationalization in the policy sciences. This study aims to fill this scholarly gap by comparing 46 public policy schools on various dimensions including degree offerings, institutional establishment and status, and mission. Further, to determine whether a unique model for public policy education is emerging that extends beyond mimicry of longstanding programs in the USA and Western Europe, we surveyed the senior management of the schools in our sample. We find that less than $25 \%$ have been directly modeled after a Western school. We discuss the implications of our findings for the practice and study of public policy education.
\end{abstract}

Keywords Public policy · Policy school $\cdot$ Higher education · Graduate education · Global South

\section{Introduction}

Public policy education has been expanding globally during the past few decades. Policy schools and programs have emerged in different parts of the world, way beyond the AngloSaxon hemisphere in which they originated. In the past 2 decades, more than 50 new policy schools were established in Africa and the Middle East, Asia, and Latin America, also known as the Global South. Scholars refer to this phenomenon as internationalization in the policy sciences (Fritzen 2008; Henderson and Terry 2014). Clearly, this expansion provides scholarly opportunities for comparatively assessing the development, content, and nature of policy education (He et al. 2016), which, in turn, may produce insights and lessons for enhancing the quality of policy education.

Sreeja Nair

sreeja.nair@u.nus.edu

1 Faculty of Public Affairs, Carleton University, Ottawa, Ontario, Canada

2 Lee Kuan Yew Centre for Innovative Cities, Singapore University of Technology and Design, Singapore, Singapore

3 Lee Kuan Yew School of Public Policy, National University of Singapore, Singapore, Singapore 
Moreover, our study is relevant as current dissatisfaction with government performance (Knott 2019) in tandem with perennial governance challenges such as corruption and lack of accountability (Fukuyama 2013) makes capacity building of public sector employees in the Global South paramount. Clearly, policy schools potentially have a massively impactful role to play in raising policy capacity and enhancing policy outcomes (Wu et al. 2012; ElTaliawi and Van der Wal 2019), even more so as public sectors across the Global South are massive employers of graduates (World Bank 2019).

Simultaneously, however, traditional Western models of governance are increasingly considered less effective, legitimate, and authoritative, with "Trumpism" and "Brexit" being significant examples of critique or even flat out rejection of traditional governance institutions. Moreover, the rapid rise and continued economic success of countries such as China, Singapore, and the United Arab Emirates have given rise to fascinating debates about whether Western-style democratic governance is a prerequisite for good governance, or perhaps decreasingly so (Fukuyama 2013; Rothstein 2015; Van der Wal 2018, 2019).

As such, an intriguing question here is whether policy programs in the Global South are well advised to model themselves after their Western counterparts, which has long been the dominant sentiment, or rather develop their own perspective on effective public policy, and whether this contributes to their popularity (cf. Bice et al. 2017; Bice and Sullivan 2014).

However, despite the recognized trend of the expansion of policy education beyond Western countries, it is less clear in which direction the field is developing (SanabriaPulido et al. 2016) and what is driving this expansion. More specifically, we lack knowledge about emerging patterns, and contextual challenges and opportunities. Where previous studies have focused on Anglo-democracies and developed countries (Pal and Clark 2016a, b; Ellwood 2008; Geva-May et al. 2006; Fritzen 2008; Zuo et al. 2019) or compared non-US-based programs to US-based programs to determine the degree of convergence (see Purón Cid 2018; He et al. 2016; Watanabe 2012), this study aims to advance our knowledge about policy schools in the Global South by comparing them on key dimensions: institutional establishment and status, mission, profile, and educational offerings.

Before we do so, however, it is pertinent to explicate our definition of public policy school, and our inclusion and exclusion criteria. First, our inventory revealed the landscape of policy degree programs is too broad to be examined in one study. Moreover, creating a reliable sampling frame for degree programs is problematic, for reasons we discuss in the methodology section. Therefore, we limit the scope of our study to schools rather than program offerings. Second, we included only schools with the following terms in their titles "public policy," "public affairs," "government," and/or "governance," and which offered graduate policy degrees. ${ }^{1}$

A third and significant issue worth mentioning is that even though we focus on Latin America, Asia, and Africa and the Middle East, and juxtapose dynamics in these regions with the Western world, we do not dare to imply that policy education in the West is itself homogenous. Indeed, policy schools in the USA are increasingly economics and management oriented, while schools in Australia, Canada, and Western Europe have traditionally been more heavily influenced by public administration and political science (cf. Botha et al. 2018). Finally, although the Global South is itself somewhat of a crude label, it serves

\footnotetext{
1 The paper's scope is limited to public policy education excluding programs and schools focusing solely on public administration and management, although management and administration related topics can of course be part of the offerings in policy schools and programs.
} 
the purpose of capturing the regions we examine while avoiding the use of a misleading Western versus non-Western dichotomy.

The following three questions guide our paper:

- What is motivating the expansion of policy education in the Global South?

- Are schools adopting a unique way of educating public policy, and if so, what are its key features?

- What are the key challenges and opportunities facing policy schools in the Global South, as well as areas for improvement?

The remainder of the article is structured as follows. First, we provide a synopsis of the origins of policy education and synthesis of scholarly literature about policy education, followed by a description of our methodology and sampling. Subsequently, we present our empirical findings on policy education in the Global South, followed by a discussion about the challenges and opportunities for emerging policy schools, and potential areas for optimization. The paper concludes with a set of recommendations for future international research into public policy education.

\section{Global policy education: what we already know}

\section{Policy education: origins and evolution}

According to seminal scholar Lasswell (1971), policy education and training serve the purpose of imparting (prospective) public servants with multidisciplinary, problem solving, and pragmatic skills and knowledge (see also Howlett et al. 2009). Specifically, Rasmussen and Callan (2016) stipulate analytical, quantitative, management, and leadership skills, enabling graduates to serve as analysts and managers in the public service, and critique the agencies in which they work-be they government agencies, private entities or civil society organizations - in order to "set things right" (Anheier 2019: 20). Therefore, when first introduced to the world, policy schools were intended to "provide for the public sector what the business schools were providing for the private sector" (Anheier 2019: 20).

When did public policy schools first emerge? With preceding developments in Europe starting in the late ninetieth century, including the introduction of cameral sciences by Fredrick William I, and courses and programs focusing on administration and state affairs (Rutgers 2003), "educational paths for pursuing policy studies at the university level emerged in the 1930s in the US" (Engelbert 1977: 228). Anheier (2019: 7) argues that the USA remains the birthplace of the policy school as we know it today, as well as the largest host of policy schools in the world. In fact, the first five policy schools were founded in the 1960s and 1970s in the USA, funded by the Ford Foundation (Evans et al. 2019).

Engelbert (1977: 228-229) describes the progress of the policy sciences in the USA as follows:

Particularly during the New Deal period many scholars of the social science disciplines became involved in public policy studies which would lead to the solution of public problems. During World War II and the years immediately following, the literature of economics, political science, and public administration reflects much interest in policy research. In the late 1940s an inter-university committee was created to develop instructional materials that were more relevant for the study of public policy 
and administration, In the ensuing years, studies dealing with all aspects of public policy appeared - with the substantive content and process of policy making, with policy formulation and implementation, and with policy methodology and evaluation.

In the same vein, Seligman (1955: 126) states in a classical piece that "public policy increasingly became adopted in the 1950s as a core concept for general education courses in the social sciences." He argues that "public policy" became a "core of curricular interest in large part a response to political and social trends" such as "growth in governmental functions, the emergence of a large public bureaucracy, the great influence of the media of mass communications, and the growth of pressure groups" (1955: 126). Ever since, policy schools and MPP and MPA degree programs have spread across the globe, as the trends he identified continued (Pal and Clark 2016b), and were supplemented with others over time, including more businesslike and economics-oriented approaches to public service, partly as a response to ever-growing government bureaucracies (Pollitt and Bouckaert 2017).

However, although policy schools and degree programs in public policy are a relatively recent phenomenon, Seligman (1955: 127) also argues convincingly how a "policy orientation in the social sciences" is far from "new," as concerns with "wise policy" and "the good society" have a long-standing tradition in social science, dating back to Plato and Aristotle. But while political science, law, and political philosophy have remained key components of most policy school curricula in Europe, and to a lesser extent Canada and Australia (Botha et al. 2018; Geva-May and Maslove 2006, 2007), from the start "public policy analysis programs at the graduate level in the US shared a focus on quantitative methods of evaluation, and action-oriented field research" (Engelbert 1977: 229), which over time has moved more and more into an econometrics and quantitatively oriented approach to policy analysis (Botha et al. 2018; Morçöl and Ivanova 2010).

So, even though "the shared goal of public policy-related programs in North America and Europe is to provide knowledge, skills and understanding of the craft of policy analysis, and the nature of the public policy process... approaches to policy analysis and research between - and within - the two regions differ; [being] highly dependent on the regional governance context and prevailing analytical culture" (Botha et al. 2018: 424).

\section{Global expansion}

Following Anglo-Saxon and Western European countries, policy programs expanded to former Soviet states and Central and Eastern Europe (Hejzlarová 2010; Mouralová et al. 2015), with Latin America, Asia and Africa recently catching up (Pal and Clark 2016a). The drivers and motivations behind the creation of policy schools in different regions appear to be very context specific. Whether policy schools established outside of the USA and Europe have followed a specific (existing) model or created unique structures of their own is subject to scholarly debate. For instance, Tan (2013, p. 130) in his analysis of the founding of the now prominent Lee Kuan Yew School of Public Policy in Singapore notes that building a public policy school in Singapore started as a "defensive rather than an introspective project," in an attempt to avoid being molded to Western models of policy thinking and discourses and instead paying close attention to the socio-cultural and historical context of Asia (at the same time, the public policy program that preceded the school was based on and established in close collaboration with the Harvard Kennedy School of Government). 
Policy courses were often the result of return migration, with scholars who had previously pursued their studies in the West starting to teach policy courses in their countries of origin (Yildiz et al. 2011; Kuo and Kuo 2012). In other instances, new schools and programs were created to cater to the rising demand for professional policy analysts and policy advisors, who were supposed to deal with the increasing complexity of policy challenges facing governments (He et al. 2016). In Brazil and East Asia, the provision of public affairs education came as a response to changes in the region's political, social, and economic systems, including the transition toward democracy (Gomes et al. 2016; Wu et al. 2012).

\section{Examining policy education in-depth: international and comparative evidence}

At first glance, studies examining policy education from an international or global perspective seem to be on the rise in recent years, as observed by Perlman (2019) in his recent review study. At the same time, however, he notes that most such studies study one country or region rather than adopting a genuine comparative approach. Examples of such single country studies examining policy education beyond the West are Yildız and Babaoğlu's (2018) and Hassen and van Jaarsveldt's (2013), on Turkey and Ethiopia, respectively.

The relatively small number of comparative studies out there has had varied geographical foci. Sanabria-Pulido et al. (2016) and Purón Cid (2018) compared patterns and trends in public affairs education in Latin America, Mexico, and the Caribbean to the evolution and character of MPA/MPP programs in the USA. Other cross-regional comparative studies include He et al. (2016) and Watanabe (2012) that focused on comparing public affairs education in China and Japan, respectively, to its counterpart in the USA.

Comparative studies, which have not used the West as a comparison group, include Bremer and El Baradei (2008)'s study comparing four master's programs in public administration and public policy in Egypt with respect to international course standards as well as local demands from the public sector in terms of related competencies and capacities; Wu et al.'s (2012) study examining public policy education in East Asia; Kuo and Kuo (2012) focusing on policy education in Taiwan; Veselý and Zelinková (2015) study on the Czech Republic; and Pellissery and Zhao (2016) comparing China and India.

Studies focusing on programs and schools have examined a variety of units of analysis, including course syllabi (Miller 2018). For instance, Wu et al. (2012) have looked at the syllabi of 62 public policy graduate courses offered in East Asia. Romero (2001), and Rethemeyer and Helbig (2005) have also analyzed course syllabi as a means of analyzing trends in the development of policy training. He et al. (2016) compared public policy analysis courses taught in China and in the USA. Purón Cid (2018) compared public policy and administration courses in LAC and the USA, in terms of their design, course sequence, and other features.

Further, previous studies have predominantly focused on MPA and MPP degree programs, rather than doctoral or other degree programs, possibly because master-level programs are easier to compare and are the most common offerings (Pal and Clark, 2016a, b) or because of the resources allocated to these programs and the number of graduates (Purón Cid 2018).

In terms of examined variables, studies have compared student profiles and attitudes among non-Western policy programs and schools (Infeld et al. 2009, 2010; Van der Wal $2017 \mathrm{a}, \mathrm{b}$ ), public policy research output as a means of assessing the state of policy research (Hung et al. 2012), and teaching capacity by comparing course instructor profiles, coverage in terms of course content and learning textbooks (Wu et al. 2012). Other variables 
examined include program structure and curriculum, sectoral focus of graduate research and matching skills to market needs (Bremer and El Baradei 2008); textbooks, course content and value paradigms and pedagogies and overall approaches to policy teaching (He et al. 2016) and the history of policy schools, structure of public policy and administration graduate programs, placements and career opportunities.

Methods used by scholars are predominantly self-reported surveys (Sanabria-Pulido et al. 2016), as well as desk research into the online environments of universities. Different sampling frames have also been used, including the US News and World Report utilized by He et al. (2016) to study the top 50 graduate programs in the 2012 rankings for public affairs.

In all, existing studies provide no conclusive evidence about the extent to which policy education in the non-Western world has adopted or copied a Western model, or whether region and country-specific course content lend uniqueness to policy programs in these regions (Purón Cid 2018; Sanabria-Pulido et al. 2016). Furthermore, a mismatch between the emphasis on theoretical understanding vis-à-vis practical application of policy education to the country context has become apparent in recent times (He et al. 2016, Bremer and El Baradei 2008).

\section{Method}

Ideally, we would have employed a global listing of public policy schools as a sampling frame for this study. When consulting with several international public policy and public affairs associations, including APPAM, IPPA, NASPAA, and PSO, we were either informed that no such listing exists, or we received no response to our inquiry. Therefore, a listing of public policy degree-awarding higher education institutions in the regions of interest was manually constructed to serve as a sampling frame. In this, we relied on the use of the QS Listing of Universities by Subject. The QS Intelligence Unit (2019), in partnership with El Sevier, compiles data annually "to help students identify potential universities in a particular subject." 2 While other university listings and rankings exist, including Times Higher Education, we specifically chose QS, because of its disciplinary and regional coverage. Times Higher Education is mainly focused on universities in the United States, while QS includes worldwide coverage.

Our initial query included all higher education institutions that offered degrees: (1) with a public policy specialization; (2) at all degree levels; and in (3) Asia, Latin America and the Middle East and Africa. The list of countries for each region was double checked to ensure that we categorized countries in the same regions (ex. Middle East is not among the QS categorizations).

The QS listing rendered 41 results in Africa and the Middle East, 170 in Asia, ${ }^{3}$ and 63 in Latin America. To clean the data, we manually checked university websites. We filtered results to include only graduate degree programs in public policy. We excluded undergraduate and non-degree programs, which are beyond the scope of our paper. We also

\footnotetext{
${ }^{2}$ More information on QS methodology can be found here https://www.topuniversities.com/subject-ranki ngs/methodology.

3 The aggregately reported number by the QS search engine was 183 , but a manual check rendered an actual result of 170 .
} 
Table 1 Sampled number of graduate policy degree programs $(n=116)$

\begin{tabular}{ll}
\hline Region & Sample size \\
\hline Africa and the Middle East & 22 \\
Asia & 64 \\
Latin America & 30 \\
\hline
\end{tabular}

Table 2 Sampled number of public policy schools $(n=46)$

\begin{tabular}{lc}
\hline Region & $\begin{array}{l}\text { Sample size } \\
\text { (no. of policy } \\
\text { schools) }\end{array}$ \\
\hline Africa and the Middle East & 9 \\
Asia & 29 \\
Latin America & 8 \\
\hline
\end{tabular}

eliminated public administration and management degrees, since our focus is on the state of policy education as a distinct field. ${ }^{4}$

To make sure that no other programs were missed, we ran a Google search using keywords: "country" (and) "policy" (and) "university." We also cross-checked our results with the relevant institutional members of the International Public Policy Association (IPPA). ${ }^{5}$ We then added any relevant results which were not included in our first rounds. Lastly, to triangulate and validate our findings, we sent the lists of universities offering public policy degrees to 48 countries and regional experts. The response rate was 53\%. Any universities missing from our lists were double checked manually and added to our list. In the end, this resulted in a sample with a total of 116 public policy graduate degree programs (see Table 1).

Subsequently, since our study is primarily interested in comparing schools of public policy in the Global South, we created a subdivision of our sampling frame, which includes only higher education institutions with actual policy schools. We define a policy school as such, if it includes in its title one of the following keywords: policy/government/governance or public affairs, and it offers one or more graduate policy degrees. Based on this, we proceeded with our analysis using a sample of 46 schools shown in Table 2. (A full list is provided in "Appendix 2").

We relied on the use of primary and secondary data collected through desk research of institutional website and online surveys. At the degree program level, we gathered data on structural affiliation (e.g., faculty/college/school/department). At the school level, we gathered data on type of graduate policy degree offerings and titles; mission/vision statements; year of founding; and disciplinary affiliations. For all universities, we collected institutional data on their organizational status: public, nonprofit, or private. At the country level, we compared the political-institutional context, using the democracy index.

We looked at these specific variables of interest to examine: (a) the institutional features across regions; (b) drivers as indicated in self-reported mission/vision statements; and (c) the political context in which policy education is provided. "Appendix 1" includes a

\footnotetext{
${ }^{4}$ For more information on coding of degrees, departments and schools, please refer to Appendix.

${ }^{5}$ Members in 2019. Teaching institutions only.
} 
Fig. 1 Policy education hierarchy

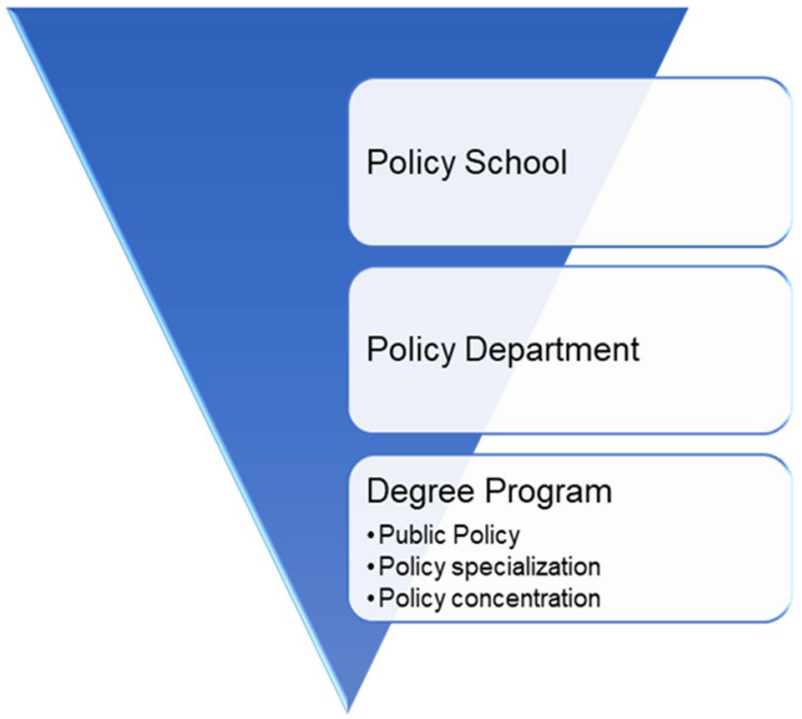

detailed description of how we coded our data, including the variables and data sources we utilized.

Subsequently, to supplement any missing data, and to answer the study's research questions that required input from the institutions themselves, we conducted an online survey. The survey consisted of open-ended and multiple-choice questions and was sent to both administrative personnel and faculty members listed on the institutional websites. We included key identifying questions aimed at ensuring respondents were either involved in the founding and/or evolution of the institution, or presently holding a position which allowed them to provide informed valid answers. The survey was sent to as many respondents as possible to ensure representation from every institution. Results were then weighted to avoid skewedness. The response rate by institution was $54 \% .^{6}$

With regard to the limitations of our study, we should note that for university websites that were not in English, or did not provide English versions of their websites, we relied on the use of "Google Translate." However, we did not encounter any specific limitation from the use of this tool that requires reporting. Further, while the QS Intelligence Unit provides information on its methodology, it does not define the specific disciplines or programs it lists under public policy specialization. Therefore, to overcome this problem, we manually checked all university websites and consulted country and regional experts.

Expert responses revealed that there could be more policy degrees offered in the three regions under examination, but which are referred to as something other than policy, such as local governance. This may be the result of certain regional or country dynamics. Therefore, it is important to note that while we tried through data and source triangulation to include a comprehensive listing of all policy schools in the three regions, our method is meant for the purpose of an exploratory research. We do not posit to generalize our findings, but we rather aim to glean an initial picture of what comprises the public policy education landscape in the Global South today. We limit our findings to the universities that

${ }^{6}$ Institutional responses: 5/8 in Latin America; 7/9 in Middle East and Africa; 13/29 in Asia. 
Table 3 Policy program disciplinary hosts and degree offerings

\section{Africa and Middle East Asia (\%)}

$(\%)$

\begin{tabular}{lccc}
\hline $\begin{array}{l}\text { Policy programs hosted in policy departments or } \\
\quad \text { schools }\end{array}$ & 63 & 64 & 27 \\
$\begin{array}{l}\text { Policy degrees offered } \\
\text { Degree in public policy }\end{array}$ & 70 & 76 & 87 \\
Degree in sectoral policy specialization & 20 & 16 & 13 \\
Degree with policy concentration & 10 & 8 & - \\
\hline
\end{tabular}

we included in our dataset, thus providing an initial mapping that hopefully encourages more systematic follow up studies.

\section{Results}

\section{Policy education: structure, degree tiers, and disciplinary distribution}

When we examined the initial landscape of 116 policy degree programs in our sample, we observed the existence of a hierarchical structure, through which policy education is offered, which we report on here before zooming in further on our main unit of analysis, which is schools (see Fig. 1).

The hierarchical pyramid-like structure, which exists, is composed of: (a) standalone policy schools; (b) policy departments; and (c) policy degree programs. We also observed that three tiers of policy degree offerings exist: (1) public policy degrees; (2) degrees with policy specializations (e.g., economic policy); and (3) degrees offering a concentration or subfield in public policy (e.g., $\mathrm{PhD}$ in Management with a concentration in public policy).

Our results indicate that in Africa and the Middle East, out of the 22 policy programs, $63 \%$ are hosted in policy schools or departments. We also observed that the majority of degrees offered by these programs $(70 \%)$ are public policy degrees, whereas $20 \%$ are degrees in sectoral policy specializations, and $10 \%$ are policy concentrations. In Asia, of the 64 programs, which offer policy degrees in our sample, $64 \%$ are hosted in schools or departments of public policy. Further, we found that $76 \%$ are public policy degrees, whereas $16 \%$ are degrees in sectoral policy specializations, and $8 \%$ are policy concentrations. In the Latin America sample, of the 30 programs which offer policy degrees, $27 \%$ are hosted in policy schools or departments. Of this, $87 \%$ are public policy degrees, $13 \%$ are degrees in sectoral policy specializations (Table 3).

Further, to determine the extent to which public policy as a field is operating as a distinct discipline in the regions under examination, we compared the disciplinary distribution of policy degree programs offered by non-policy schools or departments. To ensure consistency during coding and classification of disciplines, we relied on the use of Purón Cid (2018) codes for faculty classification. This classification uses eight categories, including public administration and public affairs, economic and administrative sciences, law, and others (full listing in “Appendix 1"). 
In the Middle East and Africa, we found a predominance of public administration and political science disciplines. Therefore, public policy followed by "public administration" and "political science" is the major disciplinary hosts of policy degrees. In the Asia sample, we found that they are predominantly hosted with other programs under the broad umbrella of social sciences. In Latin America, like Asia, the public policy programs were largely housed under the broad umbrella of social sciences, in combination with business and economics. Therefore, we conclude that policy programs are spread out across disciplines; however, public policy is the leading field offering policy education in the three regions.

While it would have been worthwhile to explore why this divergence in disciplinary spread exists, and how it affects the way in which public policy is taught across the three regions, we should refrain from speculating without conducting further analysis. Future research examining the historical evolution of the field in each region as well as content analysis of curricula may prove revealing as to whether the specific content of the school offerings studied resembles more the American tradition, the European tradition, or whether an entirely new tradition is emerging.

The most predominant type of degree offered in our sample is a degree in public policy, rather than a policy sector specialization or concentration. This leads us to conclude that public policy is establishing itself as a distinct field in the Global South, as observed in our sample. In the remainder of our paper, we concentrate our analysis on the policy schools in our sample.

\section{Policy schools: geographic distribution, institutional dynamics, and mission}

In terms of geographic distribution (Fig. 2a-c), Israel and South Africa lead the way in the number of policy schools in the Middle East and Africa region, followed by the GCC countries, and Egypt. In our Asia sample, Japan and India host the highest number of policy schools, while in Latin America, Brazil and Mexico lead the sample.

\section{Institutional establishment and status}

In terms of their founding year, policy schools in the Middle East and Africa were either founded or restructured from 1999 onward. In Asia, 79\% of the schools were established in the 2000s. In Latin America, 63\% were established in the 2000s. It is well thinkable that public policy courses and degrees may have been offered earlier, but schools were created or restructured later. Indeed, the foundation of public policy schools is a recent phenomenon in the three regions under study.

In terms of the public/private nature of the educational institutions in which the policy schools in our sample are housed, we found that $86 \%$ of the schools of public policy in our Middle East and Africa sample belonged to public universities, whereas only $22 \%$ were private. In our Asia sample, 59\% belonged to public universities. In the Latin America sample, it is found to be $50 \%$.

\section{Mission and objectives}

To assess the espoused purpose and objectives of the policy schools under study, we examined their self-reported mission and vision statements, to explore whether their 
Fig. 2 Geographical distribution of sampled policy schools. a Middle East and Africa, b Asia, c Latin America $\mathbf{a}$

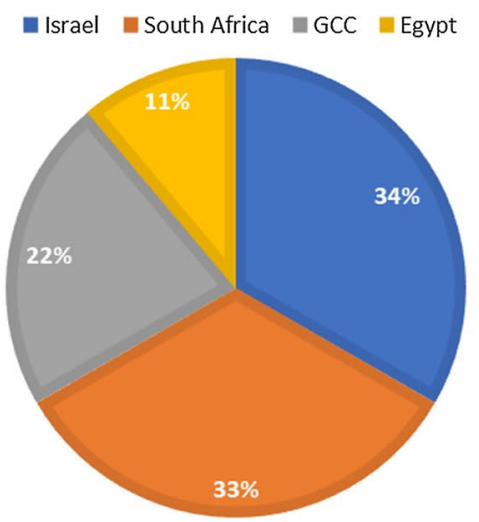

b

\begin{tabular}{|c|c|c|c|}
\hline - Japan & Endia & =South Korea $\equiv$ Cambodia & =Vietnam \\
\hline & - Malaysia & -Singapore $\|$ Russia & = Indonesia \\
\hline Thailand & =China & Eazakhstan & \\
\hline
\end{tabular}

c

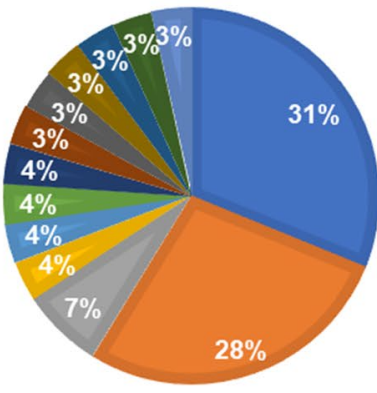

"Brazil $\|$ Mexico $=$ Colombia $\|$ Peru $\|$ Argentina $\|$ Chile

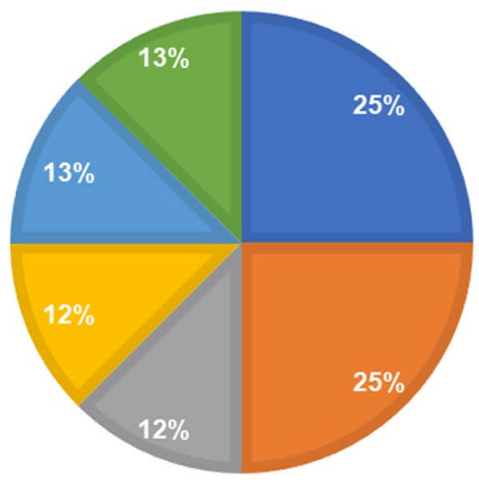

establishment is driven by a desire to meet local needs or demands, or a race to achieve international standards of excellence. To answer the key question of what new policy schools are aiming to achieve, we analyzed the content of their statements with regard to 
Table 4 Average democracy index score in 2018 (The Economist 2019)

\begin{tabular}{lllr}
\hline Middle East and North Africa & Sub-Saharan Africa & Latin America & Asia $^{\mathrm{a}}$ \\
\hline 3.54 & 4.36 & 6.24 & 5.67 \\
\hline
\end{tabular}

${ }^{a}$ Excluding Russia and Kazakhstan which are included in the index under Eastern Europe

Table 5 Political regimes by category

\begin{tabular}{llll}
\hline & $\begin{array}{l}\text { Africa and the Mid- } \\
\text { dle East }\end{array}$ & $\begin{array}{l}\text { Latin } \\
\text { America }\end{array}$ & Asia $^{\text {a }}$ \\
\hline Full democracy & 0 & 0 & 0 \\
Flawed democracy & 2 & $\mathbf{8}$ & $\mathbf{6}$ \\
Hybrid regime & 3 & 0 & 1 \\
Authoritarian & $\mathbf{4}$ & 0 & 4 \\
\hline
\end{tabular}

${ }^{\mathrm{a}}$ No information is available for Vietnam and Brunei

their intended (a) geographic focus; (b) teaching versus research focus; and (c) sectoral focus (public, private, and/or others).

In Africa and the Middle East, 66\% of policy schools reported having a regional and/ or international focus. South Africa's Mandela School of Public Governance, for instance, reported aiming "to promote and inspire strategic public leadership in Africa," while Qatar's College of Public Policy at HBKU stated having an "aim to be one of the leading public policy schools in the region and the world." With regard to functional focus, only $44 \%$ mention having a research focus, as opposed to teaching. In terms of sector focus, only Israel's Lauder School of Government mentions sectors other than the public sector in their mission/vision statements, highlighting the school's mission "to educate the next generation of leaders in the public, private and third (non-profit) sectors by providing students with high-level academic tools, practical skills and essential experience during their years of study."

In Asia, 30\% explicitly outlines a national/regional focus in the mission and vision statements. For example, the Fulbright School of Public policy and management in Vietnam noted being "devoted to advancing transformative, innovative, and inclusive public policy and management in Vietnam and the region." Similarly, Singapore's Lee Kuan Yew School of Public Policy aims to be "the leading global public policy school in Asia, developing thought leadership, improving standards of governance and transforming lives for a more sustainable world." In terms of research, 30\% of schools highlighted research as a functional focus, while all schools restrict themselves to having a public sector focus.

In Latin America, 25\% of schools' mission/vision statements had a regional/international focus. For example, Escuela de Gobierno Alberto Lleras Camargo's mission states having "scientific rigor, leadership, integrity, public service orientation and global visionto-stimulate plural dialogue and synergies between the academy and the social actors of the country and Latin America to contribute to substantial improvements in-their-societies." Similarly, Mexico's Tecnológico de Monterrey states aiming to be "the best Spanish-speaking school of government in the world; distinguished for-their-academic quality, prestige and profile of alumni, and impact in solving the most-pressing public issues." With regard to functional and sector focus, $33 \%$ of schools mentioned having a research focus, while $25 \%$ of schools only mentioned having a tri-sector focus. 
Fig. 3 Percentage of schools replicating a model (based on institutional responses)

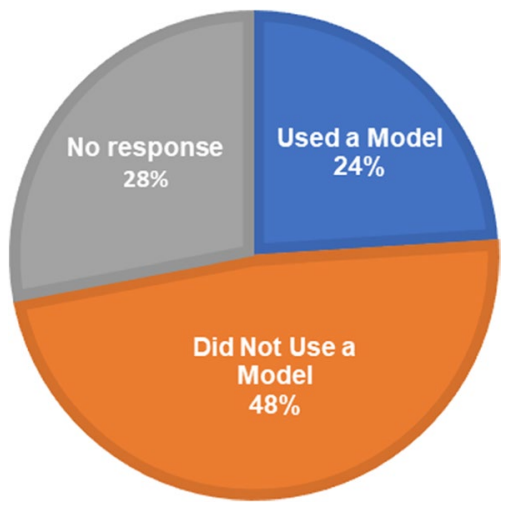

\section{Graduate degree offerings}

In terms of graduate degree offerings, we found that only $33 \%$ of schools in our Middle East and Africa sample offered doctoral studies in public policy. Otherwise, offering master's degrees is the predominant practice. In our Asia sample, the percentage of schools that offered doctoral studies was 38\%. In the Latin America sample, 50\% of schools offered doctoral studies in public policy.

\section{Macro-level political environment}

Policy schools in the Global South are situated within political regimes, which range between flawed democracies and authoritarian regimes. The average democracy index score in 2018 ranged between 3.54 in MENA and 6.24 in Latin America, as opposed to an average score of 8.56 in North America and 8.35 in Western Europe (see Tables 4 and 5).

\section{Replication or contextual profiling?}

To examine whether policy schools in the regions under examination replicate, or are inspired by, existing models of policy education, or rather shape their own unique approach and profile, we surveyed institutions in our sample to determine: (1) whether they replicated another model when initially designing their own, and (2) whether they incorporated features specific to their local context and if so, what features they incorporated. It is worthy to note that to answer this question, we relied on survey responses rather than curricula content analysis, which would have been the ideal analytical method. However, due to limitations in accessing information of this sort in the regions under examination and at the scope the paper is addressing, we opted for the self-reported survey responses. As mentioned earlier, we included in our survey key identifying questions aimed at ensuring respondents were either involved in the founding and/or evolution of the institution, or presently holding a position which allowed them to provide informed valid answers.

Among the responses received to these questions, $48 \%$ responded negatively, while $24 \%$ responded positively (Fig. 3). For those who responded positively, we asked which schools were used as a model. Results included Kennedy School of Government-Harvard 
Fig. 4 Features modeled by emerging schools (based on institutional responses)

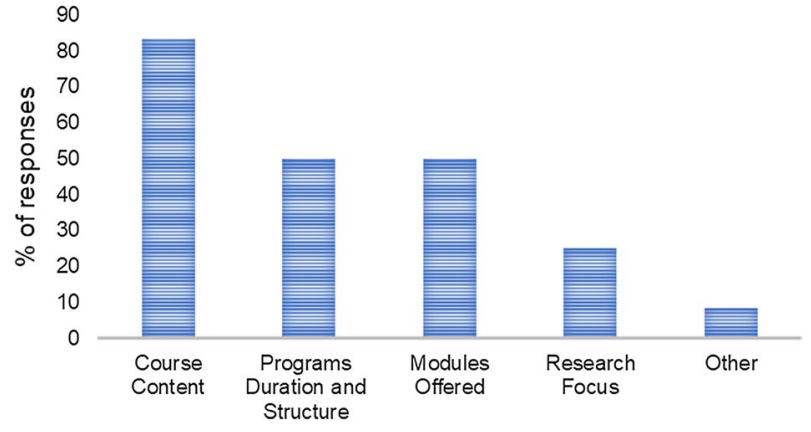

University, Lee Kuan Yew School of Public Policy-National University of Singapore, and School of International and Public Affairs-Columbia University. Other benchmarks mentioned included the Atlas of Public Policy and Management.

When asked about the specific features which were modeled by schools, course content was the major feature, followed by program structure and duration, modules offered, and research focus. Other features included financial modeling and pricing adopted.

When asked about the features incorporated in their programs and which were specific to their national or regional context, respondents mentioned either including standalone courses, such as Islamic governance and Japanese administrative law, while others mentioned the localization of course content through the use of region or country-specific case studies (Fig. 4). Thesis topic requirements were also mentioned, including the requirement to focus on country-specific policy issues. Finally, hiring practices was reported by one respondent as a way to reflect their regional character.

Therefore, we conclude, in answer to this question, that the policy schools under examination in the Global South seem to be predominantly adopting a tailored approach in creating their schools, rather than merely replicating other models, as reported by respondents. An interesting finding also includes the deliberate deployment of context-specific, non-Western models, for instance, approaches inspired by Islamic governance, Japanese administrative law and governance, and Confucianism (cf. Drechsler 2015, 2018), that may serve as benchmarks for new schools trying to find their footing and exerting confidence as emerging regional players.

\section{Implications for research and practice}

\section{Challenges and barriers}

A potential key challenge for schools in some parts of the Global South is the lack of political freedom to criticize the government. This situation may have implications on the extent of academic freedom and the ability to conduct research (Holmes and Aziz 2019). According to Janenova (2019), conducting research in "closed political contexts" can have serious ramifications on gathering and dissemination of data, among other problems. In this context, as Anderson (2019) notes, tensions may exist between "those who need answers, and those who need talking points"; potentially leading to the creation of an apolitical, technocratic policy elite. On the other hand, the increasing performance of certain illiberal countries on various global rankings may also give 
Fig. 5 Challenges facing policy schools in the global south (based on individual responses)

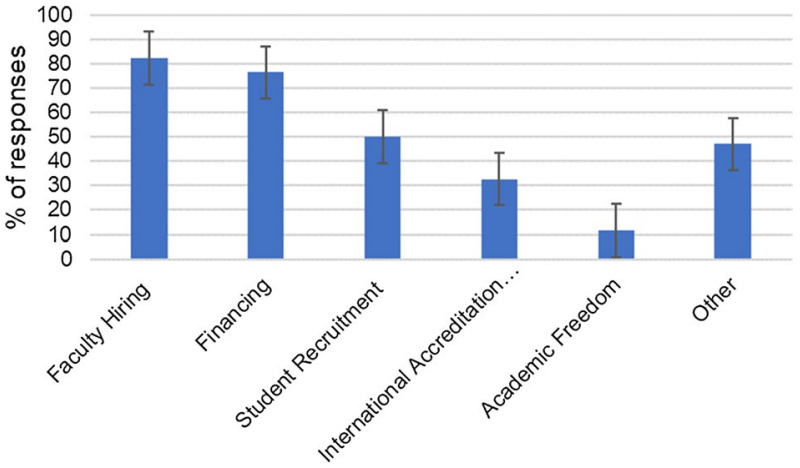

rise to a new paradigm of policy education that does not necessarily take Western-style democratic features as a starting point for (classroom and institutional) discussions about how teaching and research programs should be constructed. In fact, the success of schools and programs in Singapore, and increasingly China, and the increasing number of students they draw from Africa, may very well be explained by this fact.

Further, the lack of home-grown human capital may be an impeding factor for the growth of policy schools that would have a distinct character from their Western counterparts. However, this may be resolved as the field evolves in these regions. The lack of economic investment necessary to offer high-quality education, and the availability of job market opportunities to accommodate the rising number of policy analysts may also be a challenge to the sustainability of such programs. Moreover, the field's origins in the West, and the fact such programs are created in countries that are considered not to be the classic home base of policy science, may result in mere mimicking. This may be due to organizational tendencies for "isomorphism." In their discussion of institutional isomorphism in global policy education, Pal and Clark (2016a, b) argue that international spread of MPP programs oftentimes took the form of "franchising" leading programs, or simple emulation that was channeled through epistemic communities.

According to Rasmussen and Callan (2016), schools of public policy, among others, converge on practices because of pressures not only from a carrot-like impetus for policy schools to emulate perceived winners, but also increasing stick-like sanctions from national accreditation bodies. While such standardization bodies may be aiming to raise the quality standards of programs, this may also cause emerging schools to "adopt a run with the herd mentality" (Evans et al. 2019). Additionally, the tension between having a local versus a global focus and brand may have implications for cross-border alumni mobility. This is especially the case since brain drain is a common feature of many developing countries in the Global South. Therefore, students are likely to move from one country to the other but lack adequate balance between understanding of local and global policymaking contexts and dynamics.

In terms of key challenges faced, respondents mentioned faculty hiring (local and international) most of all, followed by access to financing. This was followed by student recruitment; meeting international accreditation demands; and academic freedom and ability to conduct research. Other challenges mentioned included: meeting national accreditation demands and translating academic resources (see Fig. 5). 


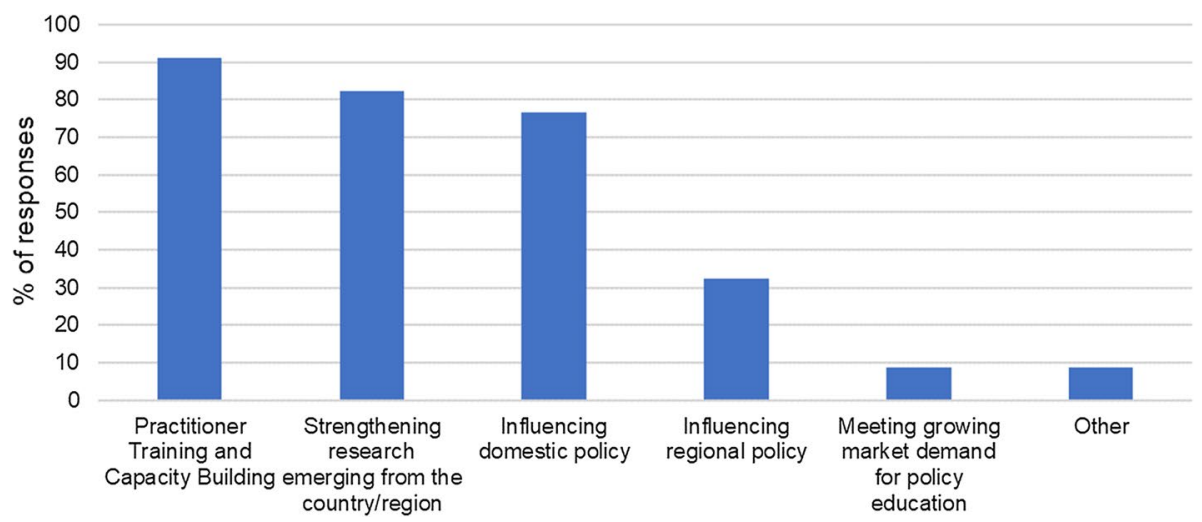

Fig. 6 Opportunities for policy schools in the global south (based on individual responses)

\section{Opportunities and potential impact}

Contrary to our prior assumption that many policy degrees are offered by non-policy disciplines, our preliminary findings indicate that the majority of degrees are offered by policy schools. This highlights that policy science as a discipline is growing apart from its traditional origins of public administration, management, and political sciences. In the words of the founding dean of the Lee Kuan Yew School of Public Policy, "public policy education is a sunrise industry" with several avenues to grow and specialize, especially in Asia (Mahbubani 2013). It is clear that there is much room for growth, given proper alignment between demand and supply of policy analysts and professionals.

There is also opportunity to improve governance outcomes by educating and training future policymakers based on a system-wide perspective and emphasis on tri-sectoral collaboration. According to Evans et al. (2019), the realignment of public service education with contemporary politics and policymaking would contribute to the restoration of trust in government.

In terms of the key opportunities perceived by respondents, practitioner training and capacity building was cited as the main area in which their policy schools can play a key role, followed by strengthening policy research emanating from their respective countries/ regions (Fig. 6). The ability to have an impact on domestic policymaking followed by regional policymaking, and meeting market demand for policy education ensued. Other opportunities for impact mentioned by respondents included: strengthening tri-sector collaboration and nurturing social entrepreneurship (cf. Van der Wal 2017c).

\section{Areas for improvement}

Based on our survey results, the following areas for improvement were mentioned by respondents. While we recognize that these continents share many similarities, they are also quite diverse; therefore, we refrain from claiming that such areas for improvement can be applicable everywhere. Here, we present these recommendations for practice from the top management of policy schools in the Global South, as a cursor to guide practitioners and educators. Since we did not find substantial cross-regional variation, we do not divide them by region, but rather by categories: 
- On Financial Resources: diversifying sources of funding, including attracting donors to allocate funding for scholarship opportunities, and increasing reliance on executive education and private tuition, to overcome financial challenges.

- On Human Capital: (1) developing a realistic and long-term approach to junior faculty development to compensate for difficulties in faculty hiring; (2) hiring locally; and (3) raising faculty salaries.

- On Administrative Practices and Academic Freedom: (1) ensuring that university-wide academic, as well administrative efforts, is made to protect students and faculty from potential undue government interference; (2) reducing bureaucratic hurdles and regulations for faculty and staff development; and (3) aligning management and faculty goals more closely.

- On Institutional Development: (1) engaging in collaboration and networking with local and international schools as a mechanism for overcoming accessibility barriers; (2) adopting resource sharing and partnering; (3) maintaining exposure to international models of best practice; (4) developing strategic plans to guide development; (5) nurturing a cutting edge policy research program; and (6) continuously innovating in curricula and teaching methods.

- On Promotion: (1) raising awareness of the relevance of policy education among potential employers and students-especially generation Y; (2) emphasizing the unique features of local approaches to governance and policymaking in the creation of schools' unique and autonomous brands; (3) providing a balance between global and local perspectives in curricular content, and adopting a tri-sectoral approach, to enhance graduates' job mobility and increase enrolment ${ }^{7}$; (4) recruiting international students; and (5) creating a competitive edge for the school in marketing efforts.

\section{Conclusion}

Our study contributes to the policy sciences literature by examining up close policy schools in the Global South: Africa and the Middle East, Asia, and Latin America, with the aim of gathering baseline descriptive empirical data on their genesis, dynamics, and prospects. Specifically, we examined their geographic dispersion, year of founding, disciplinary foci, graduate offerings, institutional nature and establishment, macro-political context as measured by countries' democracy index, and the extent to which they replicated an existing school or approach.

Our descriptive findings indicate that public policy in the Global South is asserting itself as a distinct field, evidenced by the fact that public policy is the leading field offering policy education in the three regions. In terms of geographic distribution, Israel hosts the largest number of policy schools in Africa and the Middle East, whereas Japan, Brazil, and Mexico lead the way in Asia and Latin America, respectively. Our results confirm that the establishment of policy schools is a fairly recent practice that started at the beginning of this century. Espoused purposes and objectives, as represented by schools' mission and vision statements, differ slightly between regions, but include having a regional and/or international role. In terms of degree offerings, the majority of degrees offered are at the master's degree level; in line with trends in the West, including the USA (Knott 2019). Policy schools in the Global South are also predominantly hosted by public rather than private universities. Finally, policy schools in our sample are predominantly situated within "flawed democracies" and "authoritarian" political regimes.

\footnotetext{
7 Singapore Management University was the first university globally to offer a master's degree in tri-sectoral collaboration.
} 
Most interestingly, and contrary to pre-held assumptions, the majority of emerging policy schools are not replicating Western models, but rather creating unique prototypes that speak to their local and regional character through their course content, dissertation topics requirements, and faculty hiring. While their nature as emerging schools provides opportunities, including the potential to strengthen policy research emanating from their respective countries, and having an impact on domestic policymaking, key challenges also present themselves. Such challenges include international faculty hiring and meeting international accreditation demands.

Our results can contribute to enhancing the quality of policy education provision in the Global South by deriving insights to ensure such programs are sustainable and eventually lead to better governance and policy outcomes. Given the multifaceted global domain of public policy education, adopting a one-size-fits-all prescriptive approach would not prove useful. Rather, recognizing contextual difference and emphasizing the unique features of approaches to governance and policymaking beyond the ones traditionally espoused in Western Europe and North America while capitalizing on schools' emerging unique and autonomous brands may be a more effective strategy. Non-Western approaches to policy education may also prove simultaneously useful for Western schools to learn from, thus adopting a mode of cross-cultural fertilization.

Future research may further examine variables such as student breakdown in terms of local and international body, and language of instruction, among other things. Indicators of program success and sustainability that may be further explored include enrollment and graduation statistics; faculty/student ratio; mapping out of faculty research output; faculty gender breakdown; local versus international faculty ratio; and alumni placements in the three sectors. Network analysis of international collaborations may also be conducted to determine the degree of collaboration between schools across regions. Finally, there is need for further comparative analysis that builds on this paper's initial findings by exploring convergence or divergence in curricular content and structure of degrees, internship requirements, and other criteria, as a way to move forward with this research agenda.

Funding The authors would like to declare that the open access format of this study was made possible through the financial support of Carleton University's LERRN Initiative at the Department of Political Science.

Availability of data and material All data generated or analyzed during this study are included in this published article.

\section{Compliance with ethical standards}

Conflict of interest The authors declare that they have no conflict of interest.

Code availability Not applicable.

Open Access This article is licensed under a Creative Commons Attribution 4.0 International License, which permits use, sharing, adaptation, distribution and reproduction in any medium or format, as long as you give appropriate credit to the original author(s) and the source, provide a link to the Creative Commons licence, and indicate if changes were made. The images or other third party material in this article are included in the article's Creative Commons licence, unless indicated otherwise in a credit line to the material. If material is not included in the article's Creative Commons licence and your intended use is not permitted by statutory regulation or exceeds the permitted use, you will need to obtain permission directly from the copyright holder. To view a copy of this licence, visit http://creativecommons.org/licenses/by/4.0/. 


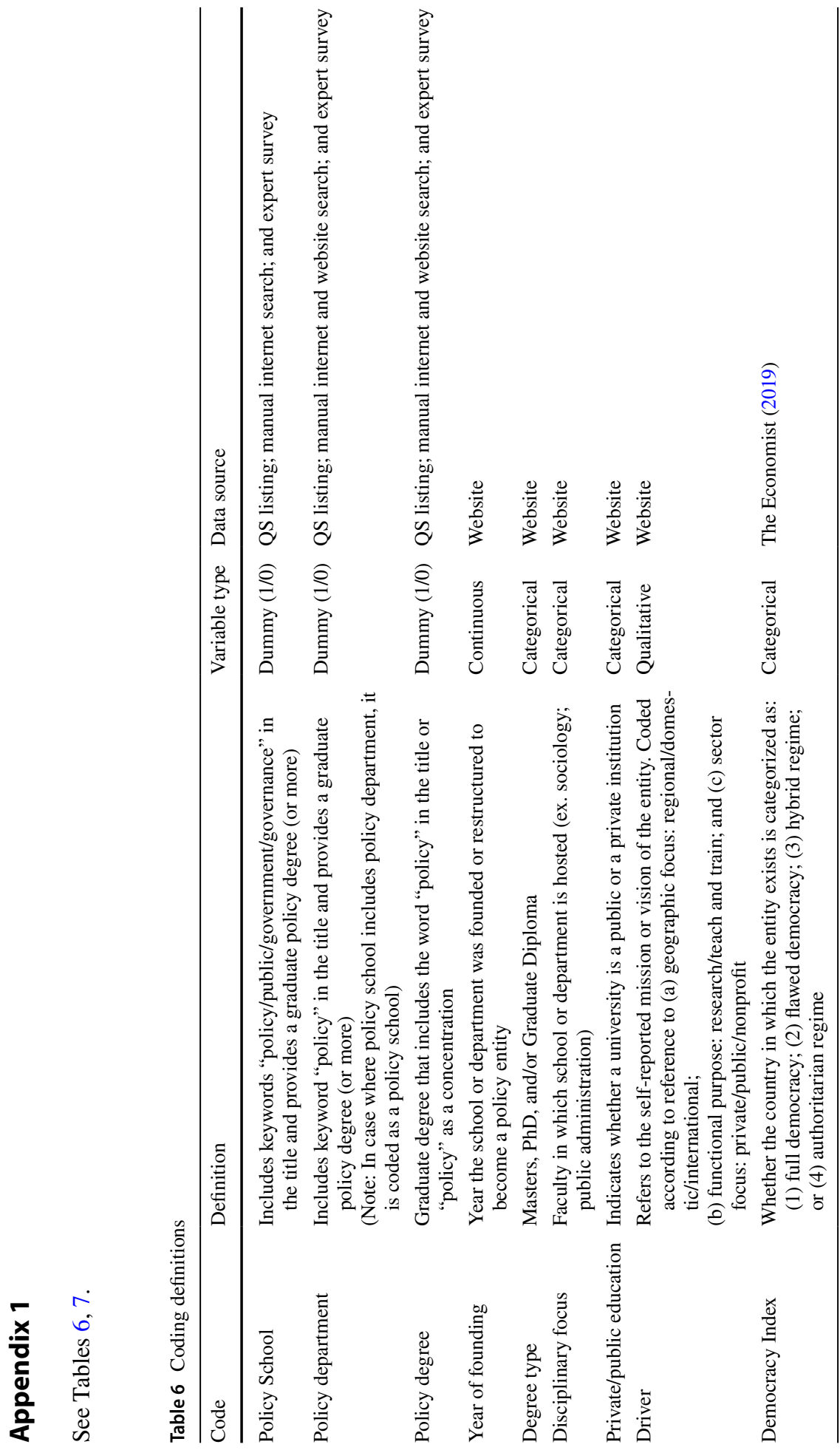


Table 7 Coding of disciplinary classifications (based on Purón Cid 2018)

Faculty/College/School Directory of terms

Economic and Administrative Sciences

Economics; Management; Accounting; Business; Entrepreneurship

Basic Sciences

Basic Sciences; Mathematics

Social Sciences and Humanities

Social Sciences; Social Work; Humanities; Human Sciences; Socio-political; Arts and Humanities; Art and Science

Political Science and International Relations Political Science; International Relations; Political; International Studies; International Affairs

Law

Law; Jurisprudence; Criminology; Justice

Public Administration and Public Affairs

Public Affairs; Public Administration; Public Management; Public Policy; Public Studies; Community/Public Service; Government; Policy

Urban Sciences

Urban Affairs; Regional Affairs

Others

Multidisciplinary; no definition

\section{Appendix 2}

See Table 8. 


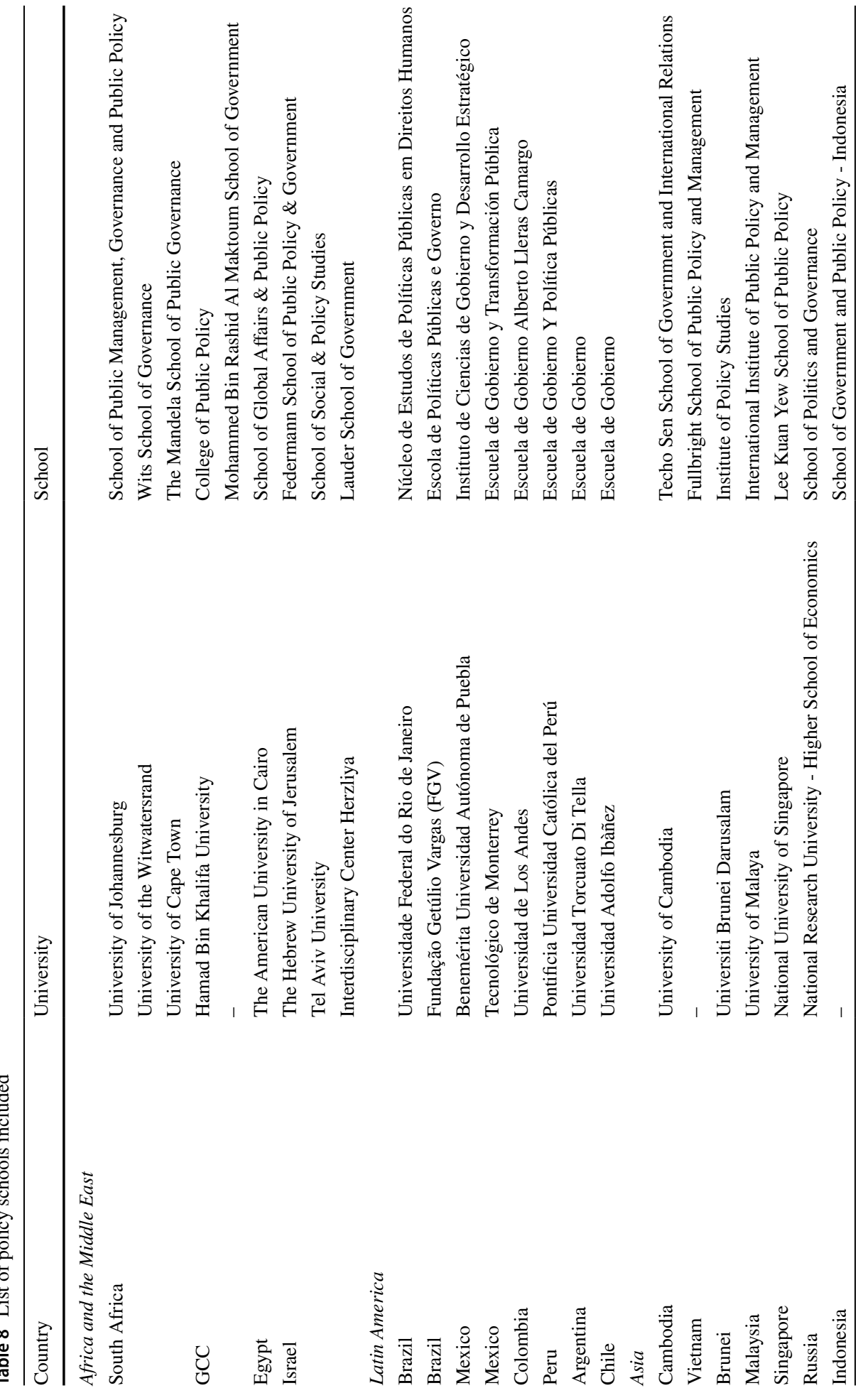




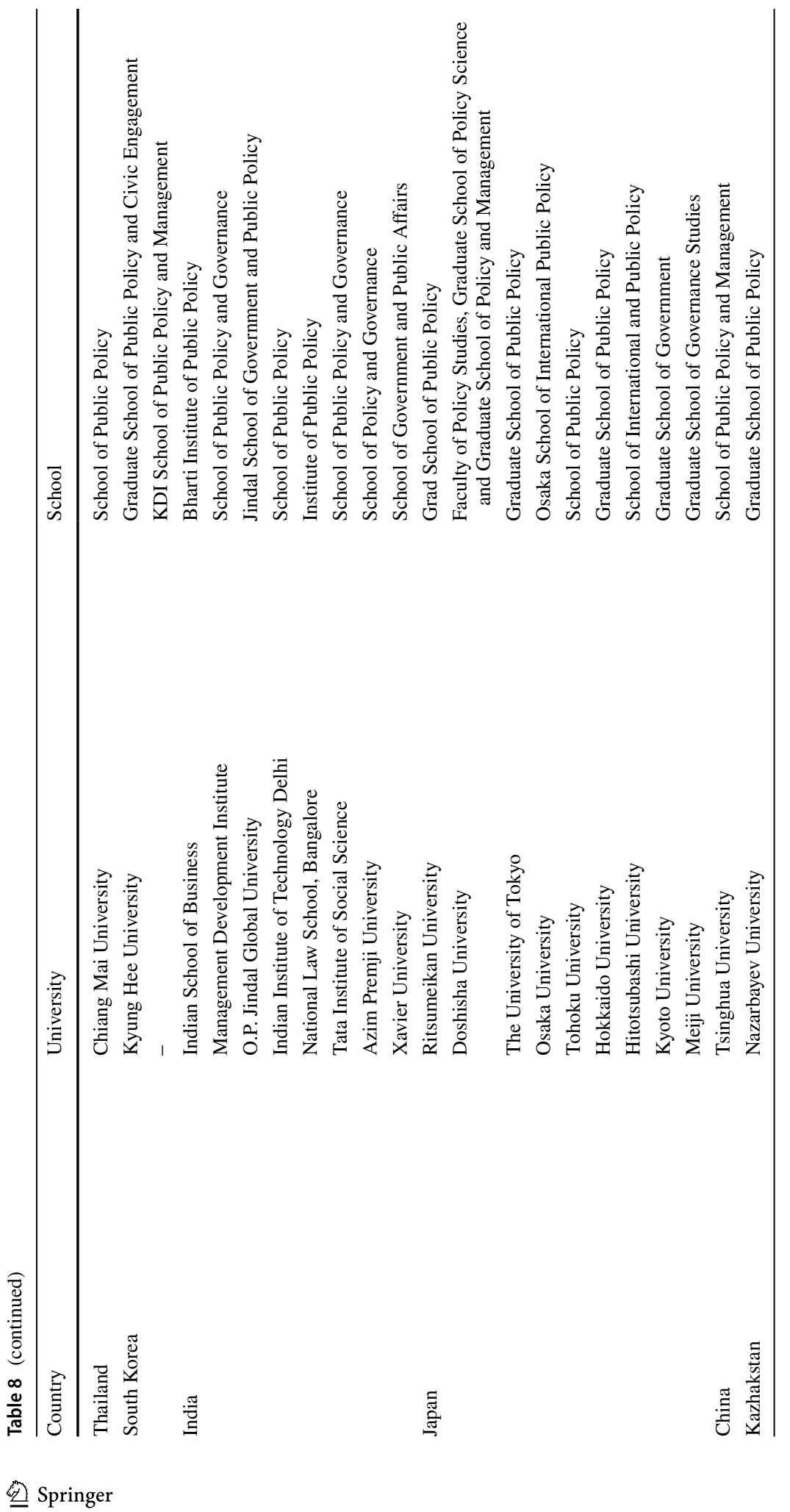




\section{References}

Anderson, L. (2019). The future of the public policy school in a world of disruptive innovation. Global Policy, 10(1), 84-85.

Anheier, H. K. (2019). On the future of the public policy school. Global Policy, 10(1), 75-83.

Bice, S., \& Sullivan, H. (2014). 1. Title: Public policy studies and the'Asian century': New orientations, challenges, and opportunities. Governance, 27(4).

Bice, S., Poole, A., \& Sullivan, H. (Eds.). (2017). Public policy in the'Asian century': Concepts, cases and futures. Springer.

Botha, J., Geva-May, I., \& Maslove, A. M. (2018). Public policy studies in North America and Europe. In L. Dobuzinskis \& M. Howlett (Eds.), Policy analysis in Canada (pp. 421-446). Bristol: Policy Press.

Bremer, J., \& El Baradei, L. (2008). Developing public administration and public policy master's programs in Egypt. Journal of Public Affairs Education, 14(3), 439-462.

Drechsler, W. (2015). Debate: Islamic PA-Does it exist, what is it, and why and how should we study it? Public Money \& Management, 35(1), 63-64.

Drechsler, W. (2018). Beyond the western paradigm: Confucian public administration. In S. Bice, A. Poole, \& H. Sullivan (Eds.), Public policy in the Asian century. Concepts, cases, and futures (pp. 19-40). London: Palgrave Macmillan.

Ellwood, J. W. (2008). Challenges to public policy and public management education. Journal of Policy Analysis and Management, 27(1), 172-187.

El-Taliawi, Ola G., \& Van Der Wal, Z. (2019). Developing administrative capacity: An agenda for research and practice. Policy Design and Practice, 2(3), 243-257.

Engelbert, E. A. (1977). University education for public policy analysis. Public Administration Review, 37(3), 228-236.

Evans, A. M., Morrison, J. K., \& Auer, M. R. (2019). The crisis of policy education in turbulent times: Are schools of public affairs in danger of becoming irrelevant? Journal of Public Affairs Education, 25, 1-11.

Fritzen, S. A. (2008). Public policy education goes global: A multi-dimensional challenge. Journal of Policy Analysis and Management, 27(1), 205-214.

Fukuyama, F. (2013). What is governance? Governance, 26(3), 347-368.

Geva-May, I., \& Maslove, A. (2006). Canadian public policy analysis and public policy programs: A comparative perspective. Journal of Public Affairs Education, 12(4), 413-438.

Geva-May, I., \& Maslove, A. M. (2007). In between trends: Developments of public policy analysis and policy analysis instruction in Canada, the United States, and the European Union. In L. Dobuzinskis, M. Howlett, \& D. Laycock (Eds.), Policy analysis in Canada: The state of the art (pp. 186-216). Toronto: University of Toronto Press.

Geva-May, I., Nasi, G., Turrinni, A., \& Scott, C. (2006, June). MPP programs emerging around the world. Paper presented at APPAM Spring Conference, Park City, Utah.

Gomes, S., Almeida, L. S., \& Lucio, M. L. (2016). A new agenda for teaching public administration and public policy in Brazil: Institutional opportunities and educational reasons. Teaching Public Administration, 34(2), 159-177.

Hassen, T. H., \& van Jaarsveldt, L. C. (2013). An overview of public administration: Education and training programmes to improve policy capacity in the Ethiopian Civil Service. Administratio Publica, 21(4), 50-66.

He, A. J., Lai, A., \& Wu, X. (2016). Teaching policy analysis in China and the United States: Implications for curriculum design of public policy programs. Policy and Society, 35(4), 385-396.

Hejzlarová, E. M. (2010). Policy analysis in the Czech Republic: Positivist or postpositivist? Central European Journal of Public Policy, 4(2), 88-107.

Henderson, A. C., \& Terry, L. D. (2014). Unpacking the global perspective: Examining NISPAcee regionfocused public administration research in American scholarly journals. International Journal of Public Administration, 37(6), 353-362.

Holmes, A., \& Aziz, S. (2019). Egypt's lost academic freedom. Carnegie Endowment for International Peace. Retrieved from, November 1st, 2019, https://carnegieendowment.org/sada/78210.

Howlett, M., Ramesh, M., \& Perl, A. (2009). Studying public policy: Policy cycles and policy subsystems (Vol. 3). Oxford: Oxford University Press.

Hung, L. C., Yu, C., Lin, M. W., \& Su, Y. C. (2012). Assessing public policy research in Taiwan: An analysis of journal publications, 1996-2007. Journal of Comparative Policy Analysis: Research and Practice, 14(5), 431-448.

Infeld, D. L., Adams, W. C., Qi, G., \& Rosnah, N. (2010). Career values of public administration and public policy students in China, Malaysia and the United States. International Journal of Public Administration, 3, 800-815. 
Infeld, D. L., Qi, G., Adams, W. C., \& Lin, A. (2009). Work values and career choices of public administration and public policy students in the U.S. and China. Presented at the IPSM Conference, June 6-8, Bloomington, Indiana.

Janenova, S. (2019). The boundaries of research in an authoritarian state. International Journal of Qualitative Methods, 18, 1609406919876469.

Knott, J. H. (2019). The future development of schools of public policy: Five major trends. Global Policy, 10(1), 88-91.

Kuo, Y. Y., \& Kuo, N. L. (2012). Taiwan's public policy education: US-style? Journal of Comparative Policy Analysis: Research and Practice, 14(5), 391-409.

Lasswell, H. D. (1971). A pre-view of policy sciences. Amsterdam: Elsevier.

Mahbubani, K. (2013). Reflections of a founding dean. In K. Mahbubani (Ed.), Lee Kuan Yew School of Public Policy: Building a global policy school in Asia (pp. 1-39). Hackensack, NJ: World Scientific Publishing.

Miller, D. R. (2018). Do undergraduate public administration, policy, and affairs programs mimic graduate curricula? Journal of Public Affairs Education, 25, 1-20.

Morçöl, G., \& Ivanova, N. P. (2010). Methods taught in public policy programs: Are quantitative methods still prevalent? Journal of Public Affairs Education, 16(2), 255-277.

Mouralová, M., Hejzlarová, E. M., Holík, R., Hubáček, M., \& Jeřábková, A. (2015). What do diploma theses unveil about Academic Public Policy in the Czech Republic? Central European Journal of Public Policy, 9(2), 164-176.

Pal, L. A., \& Clark, I. D. (2016a). The MPA/MPP in the Anglo-democracies: Australia, Canada, New Zealand, the United Kingdom, and the United States. Policy and Society, 35(4), 299-313.

Pal, L. A., \& Clark, I. D. (2016b). Teaching public policy: Global convergence or difference? Policy and Society, 35(4), 283-297.

Pellissery, S., \& Zhao, F. (2016). Challenges of teaching public policy in global south. Available at SSRN 2780859.

Perlman, Bruce J. (2019). A qualitative analysis of JPAE's international context articles: Comparative emphasis in public affairs education. Journal of Public Affairs Education, 25(1), 30-50.

Purón Cid, G. (2018). A comparative analysis of public affairs master's programs in the United States and the Latin American region. Journal of Public Affairs Education, 25, 1-29.

QS Intelligence Unit. (2019). Rankings by Subject. Retrieved from, October 31st, 2019, https://www.topunivers ities.com/subject-rankings/2019.

Rasmussen, K., \& Callan, D. (2016). Schools of public policy and executive education: An opportunity missed? Policy and Society, 35(4), 397-411.

Rethemeyer, R. K., \& Helbig, N. C. (2005). By the numbers: Assessing the nature of quantitative preparation in public policy, public administration, and public affairs doctoral education. Journal of Policy Analysis and Management, 24(1), 179-191.

Romero, F. S. (2001). The policy analysis course: Toward a discipline consensus. Journal of Policy Analysis and Management, 20(4), 771-779.

Rothstein, B. (2015). The Chinese paradox of high growth and low quality of government: The cadre organization meets Max Weber. Governance, 28(4), 533-548.

Rutgers, M. R. (2003). Retracing public administration. Emerald: Bingley.

Sanabria-Pulido, P., Rubaii, N., \& Purón, G. (2016). Public affairs graduate education in Latin America: Emulation or identity? Policy and Society, 35(4), 315-331.

Seligman, L. G. (1955). The public policy orientation and social science courses. Journal of General Education, $8(2), 126-133$.

Tan, K. P. (2013). A "Singapore School” of public policy. In K. Mahbubani (Ed.), Lee Kuan Yew School of Public Policy: Building a global policy school in Asia (pp. 127-147). Hackensack, NJ: World Scientific Publishing.

The Economist. (2019). Democracy index 2018: Me too? Political participation, protest and democracy. Retrieved from, October 31st, 2019, https://www.eiu.com/public/topical_report.aspx?campaignid=Democ racy2018.

Van der Wal, Z. (2017a). Ethos reinforced, government endorsed? Comparing pre-entry and post-entry values, motivations, sector perceptions, and career preferences of MPA students in Asia. Journal of Public Affairs Education, 23(4), 935-958.

Van der Wal, Z. (2017b). Future business and government leaders of asia. How do they differ and what makes them tick? Journal of Business Ethics, 142(3), 603-616.

Van der Wal, Z. (2017c). The 21st century public manager. London: Macmillan Education.

Van der Wal, Z. (2018). Wat is goed bestuur en wie bepaalt dat? Den Haag: CAOP. Retrieved from, https:// www.caop.nl/app/uploads/2019/05/OenA-Paper-2017-Wat_is-goed-bestuur-en-wie-bepaalt-dat.pdf. 
Van der Wal, Z. (2019). 'Macho meritocratie' Singapore. Vijf lessen uit het genadeloze streven naar ambtelijke excellentie. Bestuurskunde, 28(1), 56-65.

Veselý, A., \& Zelinková, A. (2015). Public policy programmes and policy analysis instruction in the Czech Republic. Central European Journal of Public Policy, 9(1), 50-63.

Watanabe, S. P. (2012). "Where do they belong in the job markets?" Emerging career issues of public policy program graduates in Japan. Journal of Comparative Policy Analysis: Research and Practice, 14(5), 410-430.

World Bank. (2019). Data catalog. Retrieved from, March 23rd, 2020, https://datacatalog.worldbank.org/publi c-sector-employment-share-total-employment.

Wu, X., Lai, A. Y. H., \& Choi, D. L. (2012). Teaching public policy in East Asia: Aspirations, potentials and challenges. Journal of Comparative Policy Analysis: Research and Practice, 14(5), 376-390.

Yıldız, M., \& Babaoğlu, C. (2018). Public policy education in Turkey. In G. Ertan \& C. Bakir (Eds.), Policy analysis in Turkey (pp. 271-288). London: Policy Press.

Yildiz, M., Demircioglu, M. A., \& Babaoglu, C. (2011). Teaching public policy to undergraduate students: Issues, experiences, and lessons in Turkey. Journal of Public Affairs Education, 17(3), 343-365.

Zuo, Z., Qian, H., \& Zhao, K. (2019). Understanding the field of public affairs through the lens of ranked Ph.D. programs in the United States. Policy Studies Journal, 47, S159-S180.

Publisher's Note Springer Nature remains neutral with regard to jurisdictional claims in published maps and institutional affiliations. 